\title{
PENGGUNAAN SAJAK MATEMATIKA (CINQUAINS) PADA MATERI BANGUN DATAR
}

\author{
Indah Suciati \\ Program Studi Pendidikan Matematika, FKIP,Universitas Alkhairaat \\ ndahmath@gmail.com
}

\begin{abstract}
ABSTRAK
Bangun datar ialah bagian dari Geometri yang merupakan cabang dari Matematika yang terdiri atas segitiga, segiempat, maupun segi banyak. Pengaplikasiannya pun sering digunakan dalam kehidupan sehari-hari. Namun, meskipun konsepnya sering dijumpai dan digunakan, masih banyak peserta didik yang mengalami kesulitan dalam pemahamannya. Untuk mengatasi hal tersebut, maka diberikan solusi berupa penerapan metode "sajak matematika (Cinquain)". Dalam metodenya, peserta didik diberi format yang jelas dan menarik untuk menata pemikiran dan informasi penting. Adapun langkah-langkahnya, yaitu: (1) Mengenalkan konsep Sajak Matematika (Cinquain), (2) Memberikan contoh tentang atribut atau konsep materi, (3) Memilih suatu istilah yang menjadi fokus, (4) Memberikan waktu untuk memeriksa, (5) Meminta peserta didik membuat sajak secara mandiri atau berkelompok, (6) Menunjukkan sajak yang telah dibuat.
\end{abstract}

Kata kunci : Sajak Matematika (Cinquains), Konsep, Bangun Datar

\section{ABSTRACT}

Shape is a part of Geometry which is a branch of Mathematics consisting of triangles, squares, and polygon. Its application is often used in everyday. However, even though the concept is often encountered and used, there are still many students who experience difficulties in their understanding. To overcome this, the solution is given in the method of Cinquain". In the method, students are given a clear and interesting format to organize important thoughts and information. The steps are: (1) Introducing the concept of Cinquain, (2) Providing examples of attributes or material concepts, (3) Choosing a term that is in focus, (4) Providing time to examine, (5) Asking students to make cinquan independently or in groups, (6) Showing cinquain that have been made.

Keywords: Cinquain, concept, Shape

\section{PENDAHULUAN}

Bangun datar ialah bagian dari Geometri yang merupakan cabang dari Matematika. Bangun datar terdiri atas segitiga, segiempat, maupun segi banyak. Pengaplikasiannya pun sering digunakan dalam kehidupan sehari-hari. Namun, meskipun konsep bangun datar sering kita jumpai dan kita gunakan, masih banyak peserta didik yang mengalami kesulitan dalam pemahaman konsepnya. Seperti yang dikemukakan oleh Susanti (2017) bahwa kesalahan pemahaman konsep yang dialami peserta didik pada materi bangun datar segiempat sebanyak 94,73\%. Selain itu, Ambam (2017) menyatakan bahwa peserta didik banyak yang kurang memahami konsep segi empat. Sedangkan Menurut Cahyani (2018) bahwa peserta didik 
baik field dependent maupun field independent sama-sama mengalami miskonsepsi klasifikasional dan teoritikal terhadap materi segiempat. Hal yang serupa juga dikemukakan oleh Siswandi (2016) bahwa baik laki-laki maupun perempuan sama-sama melakukan kesalahan dalam menyelesaikan masalah matematika kontekstual pada materi segiempat.

Berdasarkan hasil pemaparan di atas, karena seringnya terjadi kesalahan pada bangun segiempat baik yang dilakukan oleh peserta didik laki-laki maupun perempuan, baik yang memiliki gaya belajar Field Dependent maupun Field Independent, sehingga itu diberikan solusi berupa "Sajak Matematika (Cinquain)". Cinquain (Bentuk sajak dengan pola lima baris) merupakan cara yang dibuat agar peserta didik dapat berpikir kritis dan kreatif untuk menyaring pemahaman mereka terhadap ide dan konsep penting. Sajak matematika (Cinquain) memberi kesempatan kepada peserta didik untuk berpikir ekonomis dalam meringkas ide matematika dan informasi yang paling penting dari suatu materi matematika. Teknik sajak matematika (Cinquain) ini dibuat agar peserta didik dapat menunjukkan pemahaman konsep matematika, teorema, kosa kata, prosedur atau topik melalui penulisan kreatif dan penulisan sajak. Sajak yang berhasil tidak hanya mengikuti kaidah struktur Cinquain, tetapi juga menunjukkan bahwa peserta didik mengetahui atribut penting dari konsep matematika.

Adapun langkah-langkahnya, yaitu: (1) Mengenalkan konsep Sajak Matematika (Cinquain), (2) Memberikan contoh tentang atribut atau konsep materi, (3) Memilih suatu istilah yang menjadi fokus, (4) Memberikan waktu untuk memeriksa, (5) Meminta peserta didik membuat sajak secara mandiri atau berkelompok, (6) Menunjukkan sajak yang telah dibuat.

Penggunaan sajak matematika (Cinquain) dapat menguatkan pemahaman peserta didik terhadap masalah matematika sambil membangun kecakapan peserta didik dalam mengikuti prosedur dengan tepat, khususnya pada materi segiempat. Karena dalam sajak matematika (Cinquain), peserta didik mampu membuat dan meringkas atribut penting pada konsep segiempat. Hal ini sejalan dengan pendapat Ausubel (Jaeng, 2007) bahwa "belajar bermakna adalah suatu proses belajar, yaitu informasi (pengetahuan) baru dihubungkan dengan pengetahuan yang sudah ada". Selain itu, sajak matematika (Cinquain) juga sejalan dengan pendapat Bruner (Dahar, 2011) yang menyatakan bahwa pengajaran/instruksi hendaknya meliputi (1) pengalaman optimal bagi peserta didik untuk mau dan dapat belajar, (2) penstrukturan pengetahuan untuk pemahaman optimal, (3) perincian urutanurutan penyajian materi secara optimal, dan (4) bentuk dan pemberian reinforcement. Pendapat Gagne juga sejalan dengan pendapat Ausubel dan Bruner. Gagne mengemukakan (Dahar, 2011) bahwa lima kemampuan yang dikatakan sebagai hasil belajar yaitu keterampilan intelektual, strategi kognitif, sikap, informasi verbal, dan keterampilan motorik. Inti dari teori Gagne adalah model pemrosesan informasi. Berdasarkan beberapa teori di atas, maka dapat disimpulkan bahwa metode sajak matematika (Cinquain) dapat digunakan dalam menyelesaikan soal cerita pada materi segiempat.

\section{PEMBAHASAN}

\section{A. Belajar Pengetahuan Konsep}

Konsep adalah batu pembangun berpikir. Konsep merupakan dasar atau pondasi bagi proses mental yang lebih tinggi untuk merumuskan prinsip dan generalisasi. Konsep mnyediakan skema terorganisasi untuk mengasimilasikan stimulus baru dan menentukan hubungan di dalam dan diantara kategori-kategori. Untuk memecahkan masalah, peserta didik harus mengetahui aturan-aturan yang relevan dan aturan ini didasarkan pada konsep yang diperoleh. Konsep merupakan penyajian internal sekelompok stimulus, tidak dapat diamati, dan konsep harus disimpulkan dari suatu perilaku.

Tujuh dimensi konsep menurut Flavell (Dahar, 2011), yaitu:

a. Atribut. Setiap konsep mempunyai sejumlah atribut yang berbeda. Contohcontoh konsep harus mempunyai atribut 
yang relevan dan atribut yang tidak relevan.

b. Struktur. Struktur menyangkut cara terkaitnya atau tergabungnya atributatribut. Tiga macam struktur, yaitu:

1. Konsep konjungtif adalah konsep yang didalamnya memiliki dua atau lebih sifat sehingga dapat memenuhi syarat sebagai contoh konsep.

2. Konsep disjungtif ialah konsep yang di dalamnya terdapat satu dari dua atau lebih sifat harus ada.

3. Konsep relasional ialah hubungan antara atribut konsep.

c. Keabstrakan. Konsep dapat dilihat dan konkret atau konsep itu terdiri atas konsep lain.

d. Keinklusifan. Ditunjukkan pada contoh yang terlibat dalam konsep itu.

e. Generalitas atau keumuman. Konsep dapat berbeda dalam posisi superordinat atau subordinat jika diklarifikasikan.

f. Ketepatan. Ketepatan suatu konsep menyengkut apakah ada sekelompok aturan untuk membedakan contoh dengan non contoh suatu konsep.

g. Kekuatan. Kekuatan suatu konsep ditentukan sejauh mana orang menyetujui bahwa konsep itu penting.

Menurut Ausubel (Dahar, 2011) bahwa konsep diperoleh dengan dua cara, yaitu:

1. Pembentukan Konsep

Pembentukan konsep merupakan proses induktif. Pembentukan konsep merupakan suatu bentuk belajar penemuan dan mengikuti pola contoh/aturan. Anak yang belajar konsep dihadapkan pada sejumlah contoh dan non contoh. Mereka melalui proses abstraksi dan diskriminasi, serta menetapkan aturan yang menentukan kriteria untuk konsep itu.

2. Asimilasi Konsep

Asimilasi konsep bersifat deduktif. Dalam proses ini, anak-anak akan belajar arti konseptual baru dengan penyajian atribut-atribut kriteria konsep, kemudian menghubungkan atribut tersebut dengan gagasan/ide relevan yang telah ada dalam struktur kognitif mereka.
Dua pendekatan yang digunakan dalam belajar konsep, yaitu:

a) Pendekatan kognitif.

Pendekatan kognitif yang memusatkan pada proses perolehan konsep dalam sifat konsep dan bagaimana konsep itu disajikan dalam struktur kognitif.

b) Pendekatan perilaku.

Pendekatan perilaku menekankan pada kondisi belajar yang terjadi, yaitu kondisi internal dan kondisi eksternal.

Adapun tingkat pencapaian konsep menurut Klausmeier (Dahar, 2011), yaitu:

1) Tingkat Konkret

Pada tingkat ini, seseorang telah mencapai konsep apabila telah mengenal suatu benda yang telah dihadapinya.

2) Tingkat Identitas

Pada tingkay identitas, seseorang akan mengenal suatu objek bila sesudah selang waktu, orang itu memiliki orientasi ruang yang berbeda terhadap objek, atau jika objek itu ditentukan melalui suatu panca indera.

3) Tingkat Klasifikasi

Pada tingkat ini, peserta didik mengenal persamaan dari dua contoh yang berbeda dari kelas yang sama.

4) Tingkat Formal.

Untuk pencapaian pada tingkat formal, peserta didik harus dapat menentukan atribut-atribut yang membatasi konsep tersebut.

\section{B. Teori Belajar yang Mendukung}

Berikut ini adalah teori-teori belajar menurut para ahli yang memfokuskan kepada pengetahuan prosedural. Adapun pendapat para ahli tersebut antara lain: Bruner, Ausubel, dan Gagne.

Bruner memusatkan perhatiannya pada masalah apa yang dilakukan manusia dengan informasi yang diterimanya dan apa yang dilakukannya setelah memperoleh informasi tersebut. Hal yang penting baginya adalah bagaimana cara memilih, mempertahankan, dan mentransformasi informasi secara aktif. Pendekatan Bruner terhadap belajar didasarkan pada dua asumsi, yaitu (a) perolehan pengetahuan merupakan suatu proses interaktif, dan (b) orang mengkonstruksi pengetahuannya dengan menghubungkan informasi yang masuk dengan informasi yang disimpan 
sebelumnya. Menurut Bruner (Dahar, 2011) bahwa belajar melibatkan tiga proses yang berlangsung hampir bersamaan. Ketiga proses itu, adalah: (1) memperoleh informasi baru, (2) transformasi informasi, dan (3) menguji relevansi dan ketepatan pengetahuan. Bruner memandang bahwa belajar atau pertumbuhan kognitif sebagai konseptualisme instrumental. Pandangan ini berpusat pada dua prinsip yaitu pengetahuan seseorang didasarkan pada model-model kenyataan yang dibangun, dan model-model itu diadopsi dari kebudayaan seseorang yang kemudian diadaptasikan pada kegunaan bagi orang tersebut. Bruner juga mengemukakan tiga sistem keterampilan, yaitu: (1) tahap enaktif, (2) tahap ikonik, dan (3) tahap simbolik. Model instruksional kognitif yang sangat berpengaruh dari Jerome Bruner dikenal dengan belajar penemuan. Menurut Bruner bahwa belajar penemuan adalah usaha yang dilakukan secara aktif dan mandiri dalam mencari pemecahan masalah serta pengetahuan yang menyertainya, sehingga menghasilkan pengetahuan yang benar-benar bermakna. Bruner menyarankan agar peserta didik hendaknya belajar melalui partisipasi secara aktif dengan konsep dan prinsip sehingga mereka memperoleh pengalaman dan melakukan eksperimen yang mengizinkan mereka untuk menemukan prinsip itu sendiri.

Menurut Ausubel (Dahar, 2011) bahwa belajar dikelompokkan ke dalam dua dimensi, yaitu: (1) dimensi pertama berhubungan dengan cara informasi atau materi pelajaran yang disajikan pada peserta didik melalui penerimaan atau penemuan, (2) dimensi kedua menyangkut bagaimana cara peserta didik dapat mengaitkan informasi pada struktur kognitif yang telah ada. Inti teori Ausubel tentang belajar adalah belajar bermakna. Belajar bermakna merupakan suatu proses dikaitkannya informasi baru pada konsepkonsep yang relevan yang terdapat dalam struktur kognitif seseorang. Faktor-faktor utama yang mempengaruhi belajar bermakna ialah struktur kognitif yang ada, stabilitas, dan kejelasan pengetahuan pada waktu tertentu. Sifat-sifat struktur kognitif menentukan validitas dan kejelasan arti-arti yang timbul saat informasi baru masuk ke dalam struktur kognitif, demikian juga sifat proses interaksi yang terjadi. Bila struktur kognitif itu stabil, jelas dan diatur dengan baik, arti yang sahih dan jelas atau tidak meragukan akan timbul dan cenderung bertahan.

Menurut Gagne (Dahar, 2011) bahwa belajar konsep merupakan satu bagian dari suatu hierarki dari delapan bentuk belajar. Dalam hierarki ini, setiap tingkat belajar bergantung pada tingkat sebelumnya. Gagne menekankan bahwa kondisi internal dan kondisi eksternal dibutuhkan agar setiap bentuk belajar terjadi.

a. Kondisi internal yaitu peserta didik harus dapat membedakan contoh dan non contoh suatu konsep. Dalam mempelajari konsep terdefinisi, peserta didik harus mengeluarkan atau memanggil semua komponen konsep yang terdapat dalam definisi, termasuk hubungan antara konsep-konsep.

b. Kondisi eksternal yaitu isyarat-isyarat yang merupakan cara utama dalam belajar konsep. Dalam mempelajari konsep terdefinisi maka peserta didik dapat melakukannya dengan mengamati suatu demosntrasi. Selain mengamati dan demonstrasi, konsep terdefinisi dapat pula dinyatakan dengan verbal

Untuk belajar konsep konkret, Gagne menyarankan kondisi sebagai berikut:

1. Belajar Sinyal

2. Belajar stimulus - respon

3. Chaining

4. Asosiasi verbal

5. Belajar diskriminasi

6. Belajar konsep konkret

7. Konsep terdefinisi dan aturan

8. Pemecahan masalah.

\section{Sajak Matematika (Cinquains)}

Sajak Matematika atau Cinquains merupakan bentuk sajak dengan pola lima baris yang mengandung kalimat-kalimat matematika atau informasi-informasi penting tentang suatu materi pada matematika. Sajak matematika (Cinquains) ini merupakan alat pembelajaran yang mampu memberi kesempatan kepada peserta didik untuk berpikir secara kreatif terhadap pemahaman maupun ide dan konsep penting terhadap suatu materi 
pelajaran matematika. Teknik sajak matematika ini dapat membuat peserta didik menunjukkan pemahaman konsep matematika, teorema, kosa kata, prosedur atau topik melalui penulisan kreatif pada sajak matematika. Dalam pembuatan sajak matematika ini, siswa dituntut untuk mengetahui atribut penting dari konsep matematika.

Sajak Matematika (Cinquains) dapat menginspirasi peserta didik untuk berpikir kritis, kreatif, dan fokus pada suatu konsep inti atau ide dasar. sebelum memperkenalkan Sajak Matematika (Cinquains), guru harus menjelaskan apa itu Sajak Matematika (Cinquains), memberikan contoh dan memberikan peserta didik peluang untuk berlatih menuliskan sajak mereka berdasarkan ide atau konsep yang mereka pelajari. Sajak Matematika (Cinquains) membuat siswa berpikir terbuka (open minded) dan menghasilkan lebih banyak ide dan sajak yang lebih baik. Agar menghasilkan Sajak Matematika (Cinquains) yang baik, guru harus memberikan organizer visual terhadap peserta didik.

Setiap peserta didik dapat menuliskan Sajak Matematika (Cinquains) untuk topik yang sama atau memilih konsep dari daftar istilah atau tembok istilah. Setelah menyusun Sajak Matematika (Cinquains), peserta didik dapat menyempaikan sajak mereka dalam kelompok kecil atau kepada seluruh peserta didik di depan kelas. Penyampaian Sajak Matematika (Cinquains) dan mendiskusikannya dapat membuat peserta didik lebih nyaman dengan aktivitas ini, dan memperkuat materi matematika yang dipelajari.

Sajak Matematika (Cinquains) menantang peserta didik untuk menjelaskan pemahaman mereka terhadap konsep matematika dalam bentuk sajak. Sajak Matematika (Cinquains) mendukung standar-standar Mathematical Practice berikut:

1. Pemahaman

Pada standar ini, pemahaman berarti menjelaskan aspek dari konsep kepada diri sendiri dan memahami pendektan terhadap peserta didik yang lain.
2. Argumentasi

Standar argumentasi berarti memahami dan menggunakan asumsi, definisi dan persamaan dalam menyusun dan menjelaskan konsep.

3. Ketepatan

Dalam standar ketepatan, peserta didik mampu merumuskan penjelasan kepada yang lain dengan baik dan hati-hati.

Bentuk susunan Sajak Matematika (Cinquains), sebagai berikut:

Topik satu kata

Dua kata keterangan

Tiga kata kerja

Empat kata dalam kalimat atau frasa

Satu kata kesimpulan atau rangkuman :

Adapun langkah-langkah penerapan

Sajak Matematika (Cinquains), yaitu:

1. Mengenalkan konsep Sajak Matematika (Cinquains).

2. Memberi contoh Sajak Matematika (Cinquains) tentang atribut atau konsep suatu materi.

3. Memilih suatu istilah yang menjadi fokus atau perhatian peserta didik atau memberi kesempatan kepada peserta didik untuk memilih istilah mereka dari buku atau daftar istilah.

4. Memberikan waktu kepada peserta didik untuk memeriksa apa yang mereka ketahui tentang konsep dari sajak.

5. Meminta peserta didik membuat sajak secara mandiri atau berkelompok.

6. Mendorong pesera didik untuk menyampaikan dan mendiskusikan sajak mereka, bagaimana mereka menyusun dan konsep matematika yang digunakan.

7. Menunjukkan sajak yang telah dibuat. Penggunaan Sajak Matematika (Cinquains) di dalam kelas dapat dilakukan dengan berbagai cara. Sebagai contoh untuk meningkatkan partisipasi dan membangun ketertarikan peserta didik maka dalam pembelajarannya di dalam kelas dapat menggunakan model pembelajaran kooperatif dengan menggunakan metode permainan. Dimana, peserta didik membuat Sajak Matematika (Cinquains) secara berkelompok dan meminta kelompok lain untuk menebak judul atau baris pertama dari Sajak Matematika (Cinquains). Peserta 
didik juga dapat membaca sajak yang telah dibuat

\section{Kaitan Teori Belajar dengan Sajak Matematika (Cinquains)}

Adapun kaitan teori-teori belajar menurut para ahli dengan metode Sajak Matematika (Cinquains) dipaparkan sebagai berikut ini.

Metode Sajak Matematika (Cinquains) sejalan dengan pendapat Bruner (Dahar, 2011) yang menyatakan bahwa pengajaran/instruksi hendaknya meliputi (1) pengalaman optimal bagi peserta didik untuk mau dan dapat belajar, (2) penstrukturan pengetahuan untuk pemahaman optimal, (3) perincian urutanurutan penyajian materi secara optimal, dan (4) bentuk dan pemberian reinforcement. Tujuan belajar menurut Bruner adalah memperoleh pengetahuan dengan suatu cara yang dapat melatih kemampuan intelektual peserta didik serta merangsang keingintahuan mereka dan memotivasi kemampuan mereka. Selain itu, pengetahuan yang diperoleh menunjukkan beberapa kebaikan, seperti: (a) pengetahuan dapat bertahan lama atau lebih mudah diingat, (b) hasil belajar mempunyai efek transfer yang lebih baik. Dengan kata lain, konsep-konsep yang dijadikan milik kognitif peserta didik lebih mudah diterapkan pada situasi baru, dan (c) meningkatkan penalaran peserta didik dan kemampuan berpikir secara bebas. Hal ini dapat terlihat pada metode "Sajak Matematika (Cinquains)", dimana peserta didik membuat sajak yang berkaitan dengan suatu topik. Teknik sajak matematika ini dapat membuat peserta didik menunjukkan pemahaman konsep matematika, teorema, kosa kata, prosedur atau topik melalui penulisan kreatif pada sajak matematika. Dalam pembuatan sajak matematika ini, siswa dituntut untuk mengetahui atribut penting dari konsep matematika. Metode Sajak matematika (Cinquain) sejalan pula dengan belajar penemuan menurut Bruner, dimana:

1) Guru merencanakan pelajaran sedemikian rupa sehingga pelajaran itu terpusat pada masalah yang tepat untuk diselidiki oleh peserta didik,
2) Guru menyajikan materi pelajaran yang diperlukan sebagai dasar bagi peserta didik dalam memecahkan masalah. Seharusnya materi pelajaran mengarah pada pemecahan masalah yang aktif dan belajar penemuan.

3) Guru juga memperhatikan tiga cara penyajian, yaitu: (1) cara enaktif, (2) cara ikonik, dan (3) cara simbolik.

4) menilai hasil belajar merupakan suatu masalah dalam belajar penemuan. Tujuan tidak dapat dirumuskan secara mendetail dan tujuan tidak diminta sama untuk berbagai peserta didik. Tujuan belajar penemuan adalah mempelajari generalisasi dengan menemukan sendiri generalisasi tersebut.

Sajak matematika (Cinquain) sejalan juga dengan pendapat Ausubel (Dahar, 2011) yang mengemukakan prasyarat belajar bermakna, yaitu:

1) materi yang diajarkan harus bermakna secara potensial (memiliki kebermaknaan logis dan gagasan yang relevan harus terdapat dalam struktur kognitif)

2) peserta didik harus melaksanakan tujuan belajar bermakna. Jadi, peserta didik mempunyai kesiapan dan niat untuk belajar bermakna. Tujuan peserta didik merupakan faktor utama dalam belajar bermakna.

Pemaparan tersebut sejalan dengan pemilihan materi yang tepat untuk penggunaan Sajak matematika (Cinquain), sehingga itu materi yang dipilih adalah materi yang memuat pengetahuan konsep. Ausubel berpendapat mengenai penerapan teorinya dalam mengajar (Dahar, 2011) bahwa faktor terpenting yang mempengaruhi belajar ialah apa yang telah diketahui peserta didik. Jadi, agar terjadi belajar bermakna, maka konsep baru atau informasi baru harus dikaitkan dengan informasi yang telah ada dalam struktur kognitif peserta didik. Selain itu, prinsip yang perlu diperhatikan adalah (1) pengaturan awal, (2) diferensiasi progresif, (3) penyesuaian integratif, dan (4) belajar superordinat. Keempat prinsip tersebut, sesuai dengan langkah-langkah yang diterapkan pada sajak matematika. 
Bertolak dari model yang pemrosesan informasi oleh Gagne, Gagne mengemukakan delapan fase dalam satu tindakan belajar (learning act), yaitu: fase motivasi, fase pengenalan, fase perolehan, fase retensi, fase pemanggilan, fase generalisasi, fase penampilan, dan fase umpan balik. Selain itu, bukan hanya guru saja yang dapat memberikan instruksi, namun kejadian-kejadian belajar dapat juga diterapkan, baik dalam belajar penemuan, di luar kelas, maupun di dalam kelas. Kejadian instruksi itu adalah: (1) mengaktifkan motivasi, (2) memberi tahu tujuan-tujuan belajar, (3) mengarahkan perhatian, (4) merangsang ingatan, (5) menyediakan bimbingan belajar, (6) meningkatkan retensi, (7) melancarkan transfer belajar, dan (8) memberikan umpan balik.

\section{E. Penggunaan Sajak Matematika (Cinquain) pada Materi Bangun Datar} yaitu:

Sesuai dengan susunan Cinquains,

Topik satu kata

Dua kata keterangan

Tiga kata kerja

Empat kata dalam kalimat atau frasa

Satu kata kesimpulan atau rangkuman :

Maka, Sajak Matematika (Cinquains) tersebut dapat kita aplikasikan pada materi Bangun datar. Penggunaannya dapat menggunakan karakteristik suatu bangun datar maupun aplikasi dalam kehidupan sehari-hari.

1. Adapun penggunaan Sajak Matematika (Cinquains) dapat menggunakan karakteristik suatu bangun datar seperti berikut ini:

Segiempat

Panjang Sisi Sama

4 x S, S x S, Besar sudut sama

Digunakan dalam satuan luas

Persegi

2. Dapat pula penggunaannya dengan menggambarkan bentuk pengaplikasian suatu bangun datar, seperti berikut:

\section{Persegi panjang}

Warna Putih

Menulis, menggambar, menggaris

Ada di depan Kelas

Papan Tulis

\section{KESIMPULAN}

Bangun datar ialah bagian dari Geometri yang merupakan cabang dari Matematika. Bangun datar terdiri atas segitiga, segiempat, maupun segi banyak. Pengaplikasiannya pun sering digunakan dalam kehidupan sehari-hari. Namun, meskipun konsep bangun datar sering kita jumpai dan kita gunakan, masih banyak peserta didik yang mengalami kesulitan dalam pemahaman konsepnya. Sehingga itu diberikan solusi berupa penerapan metode "sajak matematika (Cinquain)" pada materi segiempat. Peserta didik diminta untuk membuat sajak matematika yang menunjukkan atribut atau karakteristik dari segiempat. Sajak matematika (Cinquains) ini merupakan alat pembelajaran yang mampu memberi kesempatan kepada peserta didik untuk berpikir secara kreatif dan kritis terhadap pemahaman maupun ide dan konsep penting terhadap suatu materi pelajaran matematika. Teknik sajak matematika ini dapat membuat peserta didik menunjukkan pemahaman konsep matematika, teorema, kosa kata, prosedur atau topik melalui penulisan kreatif pada sajak matematika. Dalam pembuatan sajak matematika ini, siswa dituntut untuk mengetahui atribut penting dari konsep matematika, khususnya konsep segiempat.

Sajak Matematika (Cinquains) dapat menginspirasi peserta didik untuk berpikir kritis, kreatif, dan fokus pada suatu konsep inti atau ide dasar. Setiap peserta didik dapat menuliskan Sajak Matematika (Cinquains) untuk topik yang sama atau memilih konsep dari daftar istilah atau tembok istilah yang telah ditentukan sebelumnya. Setelah menyusun Sajak Matematika (Cinquains), peserta didik dapat menyempaikan sajak mereka dalam kelompok kecil atau kepada seluruh peserta didik di depan kelas. Penyampaian Sajak Matematika (Cinquains) dan mendiskusikannya dapat membuat peserta didik lebih nyaman dengan aktivitas ini, dan memperkuat materi segiempat yang dipelajari.

Adapun langkah-langkah penerapan Sajak Matematika (Cinquains), yaitu:

1. Mengenalkan konsep Sajak Matematika (Cinquains). 
2. Memberi contoh Sajak Matematika (Cinquains) tentang atribut atau konsep suatu materi.

3. Memilih suatu istilah yang menjadi fokus atau perhatian peserta didik atau memberi kesempatan kepada peserta didik untuk memilih istilah mereka dari buku atau daftar istilah.

4. Memberikan waktu kepada peserta didik untuk memeriksa apa yang mereka ketahui tentang konsep dari sajak.

5. Meminta peserta didik membuat sajak secara mandiri atau berkelompok.

6. Mendorong pesera didik untuk menyampaikan dan mendiskusikan sajak mereka, bagaimana mereka menyusun dan konsep matematika yang digunakan.

7. Menunjukkan sajak yang telah dibuat. Penggunaan metode "sajak matematika (cinquain)" ini dapat dipadukan dengan model pembelajaran yang dianggap cocok. Dapat dipadukan dengan model pembelajaran kooperatif atau model pembelajaran lainnya. Guru juga dapat memberikan reward atau latihan lanjutan untuk memantapkan pengetahuan dan kecakapan peserta didik. Selain itu, penggunaan "sajak matematika (cinquain)" dapat pula digunakan pada materi lain yang memfokuskan pada konsep matematika

\section{DAFTAR PUSTAKA}

Amdam, Yakob. (2017). Analisis Kesalahan Siswa dalam Menyelesaikan Soal Cerita Bangun Datar Berdasarkan Pemahaman Relasional pada Siswa Kelas VII MTs Negeri Sukoharjo. Skripsi tidak diterbitkan. Surakarta: Program Studi Pendidikan Mtematika, Fakultas Keguruan dan Ilmu Pendidikan
Universitas

Muhammadiyah

Surakarta.

Cahyani, Fatmawati N. I. (2018). Analisis Miskonsepsi Siswa Materi Bangun Datar Segiempat Dibedakan dari Gaya Kognitif Siswa. Skripsi tidak diterbitkan. Surabaya: Program Studi Pendidikan Matematika, Fakultas Tarbiyah dan Keguruan, Universitas Islam Negeri Sunan Ampel.

Dahar, Ratna W. (2011). Teori-teori Belajar dan Pembelajaran. Jakarta: Erlangga

Jaeng, M. (2007). Belajar dan Pembelajaran Matematika. Palu: FKIP Universitas Tadulako

Silver, Harvey F., dkk. (2013). Pengajaran Matematika: Kurikulum Inti Bersama, Edisi Kedua. Jakarta: Indeks.

Siswandi, Erlan. (2016). Analisis Kesalahan Siswa dalam Menyelesaikan Masalah Matematika Kontekstual pada Materi Segiempat Berdasarkan Analisis Newman ditinjau dari Perbedaan Gender. Tesis tidak diterbitkan. Surakarta: Program Studi Magister Pendidikan Matematika, Universitas Sebelas Maret.

Susanti, Renita. (2017). Analisis Kesalahan Pemahaman Konsep Bangun Datar pada Siswa Kelas V MIN Sukosewu. Skripsi tidak diterbitkan. Malang: Program Studi Pendidikan Guru Madrasah Ibtidaiyah, Fakultas Ilmu Tarbiyah dan Keguruan, Universitas Islam Negeri Maulana Malik Ibrahim 